Marquette University

e-Publications@Marquette

Physics Faculty Research and Publications

Physics, Department of

$1-15-2017$

\title{
The Iron-Type Nitrile Hydratase Activator Protein Is A GTPase
}

Natalie Gumataotao

Loyola University Chicago

Karunagala Pathiranage Wasantha Lankathilaka

Marquette University, wasanthalankathilaka.karunagalapathiranage@marquette.edu

Brian Bennett

Marquette University, brian.bennett@marquette.edu

Richard C. Holz

Marquette University, richard.holz@marquette.edu

Accepted version. Biochemical Journal, Vol 474, No. 2 (January 15, 2017): pg. 247-258. DOI. (C 2017 The Author(s); published by Portland Press Limited on behalf of the Biochemical Society. Used with permission. 
NOT THE PUBLISHED VERSION; this is the author's final, peer-reviewed manuscript. The published version may be accessed by following the link in the citation at the bottom of the page.

\title{
The Iron-Type Nitrile Hydratase Activator Protein Is A GTPase
}

\author{
Natalie Gumataotao \\ Department of Chemistry and Biochemistry, \\ Loyola University Chicago, \\ Chicago, IL \\ K.P. Wasantha Lankathilaka \\ Department of Chemistry, Marquette University, \\ Milwaukee, WI \\ Brian Bennett \\ Department of Physics, Marquette University, \\ Milwaukee, WI \\ Richard C. Holz \\ Department of Chemistry, Marquette University, \\ Milwaukee, WI
}

\begin{abstract}
The Fe-type nitrile hydratase activator protein from Rhodococcus equi TG328-2 (ReNHase TG328-2) was successfully expressed and purified. Sequence analysis and homology modeling suggest that it is a G3E P-loop guanosine triphosphatase (GTPase) within the COG0523 subfamily. Kinetic studies revealed that the Fe-type activator protein is capable of hydrolyzing

Biochemical Journal, Vol 474, No. 2 (January 15, 2017): pg. 247-258. DOI. This article is @ Portland Press Limited and permission has been granted for this version to appear in e-Publications@Marquette. Portland Press Limited does not grant permission for this article to be further copied/distributed or hosted elsewhere without the express permission from Portland Press Limited.
\end{abstract}


GTP to GDP with a $k_{\text {cat }}$ value of $1.2 \times 10^{-3} \mathrm{~s}^{-1}$ and a $K_{\mathrm{m}}$ value of $40 \mu \mathrm{M}$ in the presence of $5 \mathrm{mM} \mathrm{MgCl} 2$ in $50 \mathrm{mM}$ 4-(2-hydroxyethyl)piperazine-1ethanesulfonic acid at a $\mathrm{pH}$ of 8.0. The addition of divalent metal ions, such as Co(II), which binds to the ReNHase TG328-2 activator protein with a $K_{d}$ of $2.9 \mu \mathrm{M}$, accelerated the rate of GTP hydrolysis, suggesting that GTP hydrolysis is potentially connected to the proposed metal chaperone function of the ReNHase TG328-2 activator protein. Circular dichroism data reveal a significant conformational change upon the addition of GTP, which may be linked to the interconnectivity of the cofactor binding sites, resulting in an activator protein that can be recognized and can bind to the NHase a-subunit. A combination of these data establishes, for the first time, that the ReNHase TG328-2 activator protein falls into the COG0523 subfamily of G3E P-loop GTPases, many of which play a role in metal homeostasis processes.

\section{Introduction}

Nitrile hydratases (NHases, EC 4.2.1.84) are metalloenzymes that catalyze the hydration of nitriles to their corresponding higher value amides under mild conditions (room temperature and physiological $\mathrm{pH}) .{ }^{1,2} \mathrm{NHases}$ have attracted substantial interest as biocatalysts in preparative organic chemistry and are used in the large scale industrial production of acrylamide ${ }^{1,3-6}$ and nicotinamide. ${ }^{7} \mathrm{X}$-ray crystallographic studies indicate that they are $a_{2} \beta_{2}$ heterotetramers with an active site consisting of three cysteine residues, two amide nitrogens, a water molecule, and either a nonheme Fe(III) ion (Fetype) or a noncorrin Co(III) ion (Co-type). ${ }^{8,9}$ Two of the active site cysteine residues are post-translationally modified to cysteine sulfinic acid $\left(-\mathrm{SO}_{2} \mathrm{H}\right)$ and cysteine sulfenic acid $(-\mathrm{SOH})$, yielding an unusual metal co-ordination geometry, termed a 'claw-setting'. Oxidation of the equatorial Cys residues is required for catalytic activity. ${ }^{10,11}$

Even though the structures of Fe- and Co-type NHases are very similar, Fe-type NHases are specific for Fe(III), whereas Co-type NHases are specific for Co(III). ${ }^{8}$ Several open reading frames have been identified just downstream from the structural a- and $\beta$-subunit genes in NHases, and one of these genes has been proposed to function as an activator protein (Figure 1). ${ }^{12-14}$ The prevailing dogma is that both $\mathrm{Co}$ - and Fe-type NHase enzymes require the co-expression of an activator protein to be fully metallated, post-translationally modified, and fully functional. ${ }^{12-14}$ While Co- and Fe-type NHase enzymes share high sequence similarity, their respective activator proteins are different in size and share little to no sequence identity,

Biochemical Journal, Vol 474, No. 2 (January 15, 2017): pg. 247-258. DOI. This article is (C) Portland Press Limited and permission has been granted for this version to appear in e-Publications@Marquette. Portland Press Limited does not grant permission for this article to be further copied/distributed or hosted elsewhere without the express permission from Portland Press Limited. 
NOT THE PUBLISHED VERSION; this is the author's final, peer-reviewed manuscript. The published version may be accessed by following the link in the citation at the bottom of the page.

suggesting that the mechanism of metallocenter assembly is probably different between Co- and Fe-type NHase enzymes. ${ }^{15-17}$

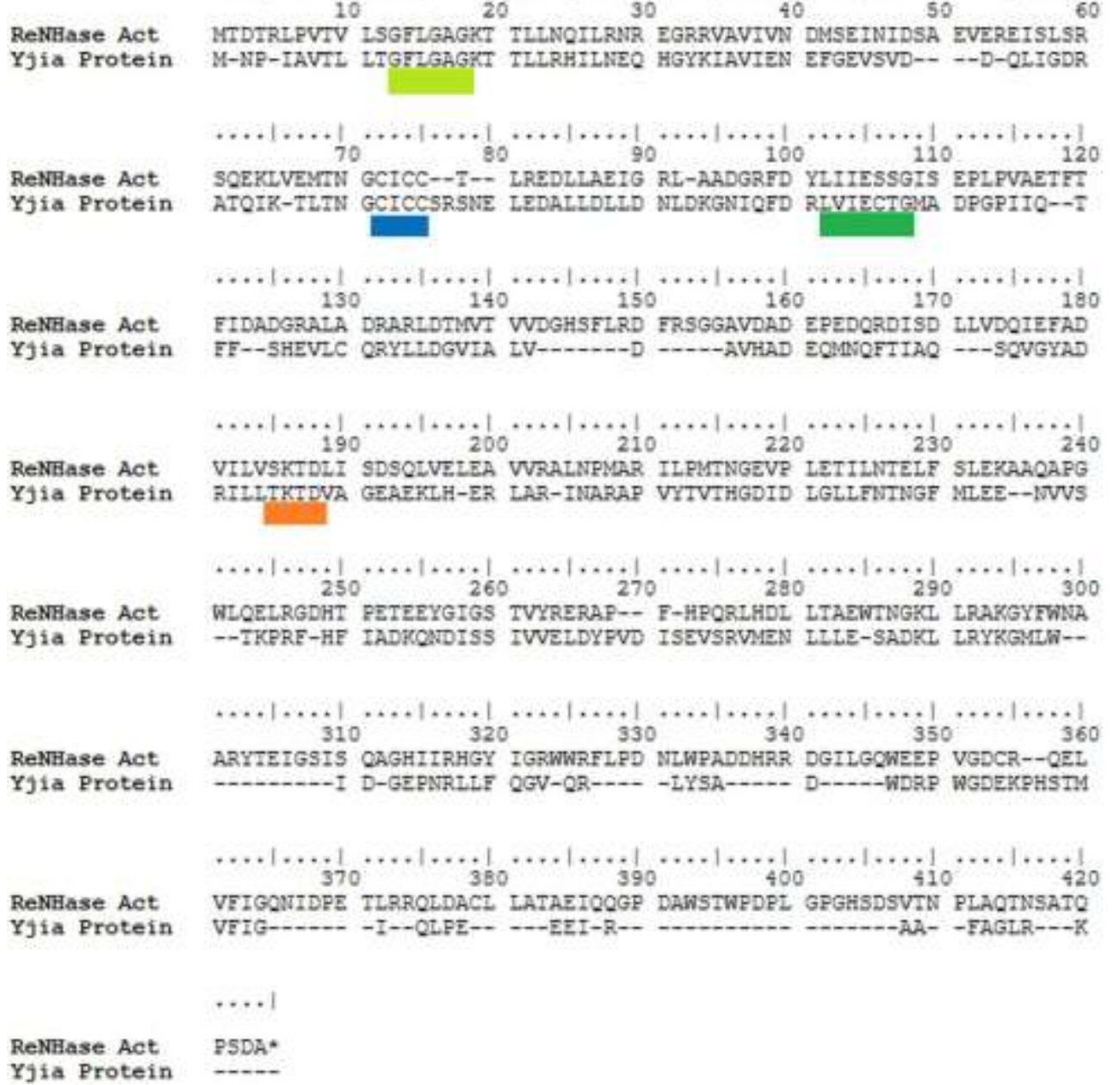

Figure 1. Sequence alignment of Yjia and the Fe-type ReNHase TG328-2 activator protein.

The alignment shows (light green - Walker A motif; dark green - Walker B motif; blue - metal-binding motif; orange - guanine-binding motif) shows conserved regions common to P-loop GTPases that are probably responsible for GTPase activity of the proteins.

Activator proteins $(\varepsilon)$ for cobalt-type NHases are small $(\sim 15$ $\mathrm{kDa})$ and have a significant sequence identity with the NHase $\beta$ subunit. ${ }^{18,19}$ The Co-type activator protein for the low-molecularweight NHase from Rhodococcus rhodochrous $\mathrm{J} 1$ has been shown to form an $a \varepsilon_{2}$ complex, which was proposed to bind $\mathrm{Co}$ (II) and insert it into the apo- $a_{2} \beta_{2}$ NHase complex via a 'self-subunit swapping' mechanism. ${ }^{17}$ The Co-type activator protein was also proposed to

Biochemical Journal, Vol 474, No. 2 (January 15, 2017): pg. 247-258. DOI. This article is (C) Portland Press Limited and permission has been granted for this version to appear in e-Publications@Marquette. Portland Press Limited does not grant permission for this article to be further copied/distributed or hosted elsewhere without the express permission from Portland Press Limited. 
facilitate the oxidation of the two active site Cys residues. On the other hand, Fe-type NHase activator proteins are $45 \mathrm{kDa}$ and contain a highly conserved cysteine-rich (CXCC) motif that is a known metalbinding site in other metallochaperones, such as COX17 (copper) and the Hyp proteins (nickel). ${ }^{20,21}$

To date, no Fe-type activator protein has been purified or characterized. As such, no molecular level evidence exists regarding the structure or function of the Fe-type NHase activator protein in the biosynthesis of Fe-type NHase enzymes. Therefore, we set out to purify the Fe-type activator from Rhodococcus equi TG328-2. The gene encoding the activator protein was synthesized with optimized Escherichia coli codon usage and heterologously overexpressed in $E$. coli as a maltose-binding protein (MBP)-protein construct. The resulting protein binds divalent metal ions and can function as a guanosine triphosphatase (GTPase). The hydrolysis of GTP by a Fetype NHase activator protein is a previously unknown role that may be connected to NHase metallocenter assembly.

\section{Materials and methods}

\section{Materials}

2-amino-2-hydroxymethyl-propane-1,3-diol (Tris- $\mathrm{HCl}$ ), and 4(2-hydroxyethyl)piperazine-1-ethanesulfonic acid (HEPES) were obtained from Sigma-Aldrich. Oligonucleotides were obtained from Integrated DNA Technologies, Inc. All other reagents were purchased commercially and were of the highest purity available.

\section{Plasmids}

The plasmid expressing the Fe-type NHase from $R$. equi TG3282 (ReNHase TG328-2) was kindly provided by Prof. Uwe Bornscheuer (University of Greisfwald). ${ }^{22}$ The original plasmid had the NHase a, $\beta$, and activator genes in tandem. NHases are typically expressed when the genes for the $a$ - and $\beta$-subunits and the activator are co-expressed on separate, complementary plasmids. Therefore, the a- and $\beta$-subunit and activator genes from the original plasmid were isolated and subcloned into pET-21a+ and pET-28a+ plasmids, respectively. The 
activator was removed from the $\mathrm{pET}-28 \mathrm{a}^{+}$plasmid and ligated into pMCSG9 forming the ReNHase(e)-MBP-His6 plasmid containing a tobacco etch virus (TEV) protease cleavage site between MBP and the ReNHase $(\varepsilon)$ protein. ${ }^{23}$ All plasmid sequences were confirmed using automated DNA sequencing at the University of Chicago Cancer Research Center DNA sequencing facility.

\section{Expression and purification of the recombinant ReNHase activator protein}

The ReNHase $(\varepsilon)-\mathrm{MBP}-\mathrm{His}_{6}$ plasmid containing the Fe-activator protein was transformed into BL21(DE3) (Stratagene) cells for gene expression. A single colony from the transformation was used to inoculate a $50 \mathrm{ml}$ LB Miller culture containing $50 \mu \mathrm{g} / \mathrm{ml}$ kanamycin and allowed to grow at $37^{\circ} \mathrm{C}$ with constant shaking overnight. This culture was used to inoculate 3 I of LB Miller culture containing kanamycin (50 $\mu \mathrm{g} / \mathrm{ml})$ and ampicillin $(100 \mu \mathrm{g} / \mathrm{ml})$. Cells were allowed to grow at $37^{\circ} \mathrm{C}$ with constant shaking until an optical density of $\sim 0.8-1.0$ at $600 \mathrm{~nm}$ was reached. The culture was cooled to $18^{\circ} \mathrm{C}$ and induced with $0.1 \mathrm{mM}$ isopropyl- $\beta$ - $d$-1-thiogalactopyranoside and then shaken for 16 additional hours at $18^{\circ} \mathrm{C}$.

Cells were pelleted by centrifugation at $5000 \times \boldsymbol{g}$ for $5 \mathrm{~min}$ and resuspended in $50 \mathrm{mM}$ sodium phosphate buffer $(\mathrm{pH} \mathrm{8.0)}$ containing $300 \mathrm{mM} \mathrm{NaCl}, 10 \%$ glycerol, and $10 \mathrm{mM}$ imidazole at a ratio of $3 \mathrm{ml} / \mathrm{g}$ of cells. Cells were lysed by ultrasonication (Misonix Sonicator 3000) in $30 \mathrm{~s}$ increments for $4 \mathrm{~min}$ at $21 \mathrm{~W}$. Cell lysate was separated from cell debris by centrifugation for $40 \mathrm{~min}$ at $10000 \times \boldsymbol{g}$. Cell lysate was purified using immobilized metal affinity chromatography (IMAC) on a GE ÄKTA Fast Protein Liquid Chromatography (FPLC) system at $4^{\circ} \mathrm{C}$. The protein was eluted from the nickel nitrilotriacetic acid (Ni-NTA) column (100 $\mathrm{mg}$ protein/5 $\mathrm{ml}$ column) with a linear gradient (0-100\%) of a high imidazole content buffer [50 mM NaH $\mathrm{PO}_{4}(\mathrm{pH} 8.0), 300 \mathrm{mM}$ $\mathrm{NaCl}, 10 \%$ glycerol, and $500 \mathrm{mM}$ imidazole] at a flow rate of $1 \mathrm{ml} / \mathrm{min}$.

Fractions containing the Fe-type activator protein were treated with $\mathrm{His}_{6}$-tagged TEV protease $(5 \% \mathrm{w} / \mathrm{w})$ and $2 \mathrm{mM}$ dithiothreitol and stirred gently overnight at $4^{\circ} \mathrm{C}$. Cleaved protein was purified with IMAC by eluting unbound protein with $100 \%$ of a $10 \mathrm{mM}$ imidazole buffer

Biochemical Journal, Vol 474, No. 2 (January 15, 2017): pg. 247-258. DOI. This article is (C) Portland Press Limited and permission has been granted for this version to appear in e-Publications@Marquette. Portland Press Limited does not grant permission for this article to be further copied/distributed or hosted elsewhere without the express permission from Portland Press Limited. 
solution. The protein was then concentrated to $2 \mathrm{ml}$ and loaded onto a $25 \mathrm{ml}$ DEAE-Sepharose (diethylaminoethyl) column equilibrated with anion exchange buffer $A$ [ $10 \mathrm{mM}$ Tris $(\mathrm{pH} 8.0)$ and $10 \mathrm{mM} \mathrm{NaCl}$. The protein was eluted in a stepwise gradient at $50 \%$ of buffer $B$ [10 mM Tris ( $\mathrm{pH} \mathrm{8.0)}$ and $500 \mathrm{mM} \mathrm{NaCl}$. The purified protein was then bufferexchanged using an Amicon centrifugal concentrator (Millipore) into 50 mM HEPES ( $\mathrm{pH} 8.0$ ) and $300 \mathrm{mM} \mathrm{NaCl}$.

Approximately $5 \mathrm{mg} / \mathrm{l}$ purified activator protein per liter of culture was obtained. The protein precipitated upon cleavage of the MBP tag, so optimal conditions for solubilization were determined by employing a solubility screen ${ }^{24}$ providing optimal conditions of $50 \mathrm{mM}$ HEPES (pH 8.0), $300 \mathrm{mM} \mathrm{NaCl}$, and 10\% glycerol. Under these conditions, the activator protein was stable at $4^{\circ} \mathrm{C}$ for several days. Purification of the activator was confirmed by sodium dodecyl sulfatepolyacrylamide gel electrophoresis. A Bradford assay was performed at $595 \mathrm{~nm}$ against bovine serum albumin standards to determine protein concentration.

\section{Nucleotide triphosphatase activity measurement}

Nucleotide triphosphatase (NTPase) activity was assayed in triplicate for three separate purifications, using a malachite green assay at NTP [GTP, adenosine triphosphate (ATP), or uridine triphosphate (UTP)] concentrations ranging from 0.05 to $1 \mathrm{mM}$ and Feactivator protein concentrations of $1-3 \mu \mathrm{M}$ in $50 \mathrm{mM}$ HEPES ( $\mathrm{pH}$ 8.0) and $5 \mathrm{mM} \mathrm{MgCl}$ at $37^{\circ} \mathrm{C}$ for $5-240$ min. ${ }^{25}$ The reaction was quenched by the addition of $375 \mu$ of malachite green ( $2.6 \mathrm{mM}$ malachite green, $1.5 \%$ ammonium molybdate, and $0.2 \%$ Tween 20 ), incubated at room temperature for $1 \mathrm{~min}$ followed by the addition of sodium citrate to a final concentration of $3.5 \mathrm{mM}$. The absorbance was measured at 630 $\mathrm{nm}$ on a BioTek Synergy 2 Multimode microplate reader and compared with a prerecorded calibration curve. One unit of enzymatic activity is defined as the amount of enzyme catalyzing the formation of $1 \mu \mathrm{mol}$ $\mathrm{min}^{-1} \mathrm{PP}_{\mathrm{i}}$. Error values were determined by averaging all kinetic determinations for each NTP.

Biochemical Journal, Vol 474, No. 2 (January 15, 2017): pg. 247-258. DOI. This article is (C) Portland Press Limited and permission has been granted for this version to appear in e-Publications@Marquette. Portland Press Limited does not grant permission for this article to be further copied/distributed or hosted elsewhere without the express permission from Portland Press Limited. 
NOT THE PUBLISHED VERSION; this is the author's final, peer-reviewed manuscript. The published version may be accessed by following the link in the citation at the bottom of the page.

\section{Metal analysis}

Inductively coupled plasma atomic emission spectroscopy (ICPAES) analysis was conducted at the Integrated Molecular Structure Education and Research Center (IMSERC) at Northwestern University. All glassware was washed with $1 \mathrm{M} \mathrm{HNO}_{3}$ prior to use and all buffers were demetallated by using a Chelex-100 column. Purified activator protein was digested in a $5 \%$ nitric acid $\left(\mathrm{HNO}_{3}\right)$ solution for $15 \mathrm{~min}$ at $70^{\circ} \mathrm{C}$. The digested protein was filtered through a $0.2 \mu \mathrm{m}$ Supor membrane (Whatman). The filtered samples were analyzed for iron (238.204 and $259.940 \mathrm{~nm}$ ), nickel (230.299 and $231.604 \mathrm{~nm})$, and zinc (202.548 and $213.857 \mathrm{~nm})$.

\section{Electronic absorption spectra}

Electronic absorption spectra were recorded on a Shimadzu UV2600 spectrophotometer equipped with a TCC-240A temperaturecontrolled cell holder. Spectra of the Fe-type activator protein, in 50 mM HEPES (pH 8.0), $300 \mathrm{mM} \mathrm{NaCl}$, and $10 \%$ glycerol, were obtained at $25^{\circ} \mathrm{C}$ in a $1 \mathrm{~cm}$ quartz cuvette.

\section{Isothermal titration calorimetry}

Isothermal titration calorimetry (ITC) measurements were carried out on a MicroCal ITC200 system. The Fe-type activator protein was incubated with $10 \mathrm{mM}$ ethylenediaminetetraacetic acid (EDTA) in the presence of $20 \mathrm{mM}$ tris(2-carboxyethyl)phosphine (TCEP), used as a reducing agent, at $4^{\circ} \mathrm{C}$ anaerobically for $24 \mathrm{~h}$ in degassed $50 \mathrm{mM}$ HEPES buffer ( $\mathrm{pH}$ 7.5). The EDTA was removed by dialysis using, at minimum, four buffer exchanges of $50 \mathrm{mM}$ Chelex-treated HEPES buffer at a $\mathrm{pH}$ of 7.5. Individual Fe-type activator protein and Co(II) solutions were prepared by diluting stock enzyme or $\mathrm{Co}$ (II) solutions with degassed $50 \mathrm{mM}$ Chelex-treated HEPES buffer $(\mathrm{pH} 7.5)$ containing $2 \mathrm{mM}$ TCEP and incubated at $4^{\circ} \mathrm{C}$ for $24 \mathrm{~h}$. The enzyme solution (50 $\mu \mathrm{M})$ was placed in the calorimeter cell and stirred at $750 \mathrm{rpm}$ to ensure rapid mixing. Typically, $2 \mu$ of $\mathrm{Co}$ (II) titrant $(500 \mu \mathrm{M})$ was delivered over $2 \mathrm{~s}$ with a 3 min interval between injections to allow for complete equilibration. Each titration was continued to $>2$ equiv. of added Co(II) to ensure that no additional complexes were formed with excess 
titrant. A background titration, consisting of the identical titrant solution but only the buffer solution in the sample cell, was subtracted from each experimental titration to account for heat of dilution.

Association constants $\left(K_{\mathrm{b}}\right)$ were obtained by fitting these data, after subtraction of the background heat of dilution, via an interactive process using the Windows-based Origin software package supplied by MicroCal. This software package uses a nonlinear least-squares algorithm, which allows the concentrations of titrant and the sample along with the heat flow per injection to be fit to an equilibrium binding equation. The $K_{\mathrm{b}}$ value, enzyme-metal stoichiometry $(n)$, and the change in enthalpy $\left(\Delta H^{\circ}\right)$ were allowed to vary during the fitting process. The association constant $K_{\mathrm{b}}$ and the enthalpy change $\Delta H$ were used to calculate $\Delta G$ and $\Delta S$ using the Gibbs-free energy relationship (eqn 1):

$$
\Delta G^{\circ}=-R T \ln \left[K_{\mathrm{b}}\right]=\Delta H^{\circ}-T \Delta S_{1}^{\circ}
$$

where $R=1.9872 \mathrm{cal} \mathrm{mol}^{-1} \mathrm{~K}^{-1} . T$ is temperature in $\mathrm{K}$. The relationship between $K_{\mathrm{b}}$ and $K_{\mathrm{d}}$ is defined as

$$
K_{\mathrm{d}}=\frac{1}{K_{\mathrm{b}} 2}
$$

\section{Circular dichroism}

A $3 \mu \mathrm{M}$ sample of purified activator was prepared in $10 \mathrm{mM}$ sodium phosphate ( $\mathrm{pH} 7.5)$. Spectra were collected from 190 to 260 $\mathrm{nm}$ on samples in a $1 \mathrm{~mm}$ path-length quartz cell on an Olis DSM circular dichroism (CD) spectrometer. The program CDSSTR (Birkbeck College DICHROWEB reference set 4) was used to analyze the secondary structure of the activator. ${ }^{26,27} \mathrm{CD}$ spectra were also recorded of the Fe-activator protein in the presence of GTP, ATP, GDP, $\mathrm{Mg}(\mathrm{II})$, or $\mathrm{Co}(\mathrm{II})$.

\section{Homology modeling}

The sequence of the ReNHase TG328-2 Fe-activator protein was submitted to SWISS-MODEL. ${ }^{28-30}$ A protein database (PDB) blast search identified the YjiA protein (PDB: 1NIJ) as the best template

Biochemical Journal, Vol 474, No. 2 (January 15, 2017): pg. 247-258. DOI. This article is (C) Portland Press Limited and permission has been granted for this version to appear in e-Publications@Marquette. Portland Press Limited does not grant permission for this article to be further copied/distributed or hosted elsewhere without the express permission from Portland Press Limited. 
structure. The resulting homology model was exported to Deepview Swiss PDB Viewer for further refinement and model validation. ${ }^{31}$ ProCheck ${ }^{32}$ and Verify $3 \mathrm{D}^{33}$ were run in order to validate the homology model. The Ramachandran plot of the ReNHase TG328-2 activator protein homology model revealed that only $1.5 \%$ of the structure is in a disallowed region. That combined with a QMEAN score of 0.506 indicates that the model is a reasonable predictive tool.

\section{Results and discussion}

\section{Expression of the ReNHase TG328-2 activator protein}

A major limitation in examining the proposed metallochaperone properties of a Fe-type NHase activator protein is the lack of an expression system that provides ample amounts of a soluble form of the protein. We have overcome these issues by subcloning the ReNHase TG328-2 activator gene into the PMCSG9 plasmid, which contains an $\mathrm{N}$-terminal TEV protease cleavage site followed by MBP and a $\mathrm{His}_{6}$ tag. The MBP was incorporated to aid protein folding during expression, whereas the His 6 tag allows rapid purification via IMAC. This plasmid was then transformed into BL21(DE3) (Stratagene) cells for protein expression. Purification using IMAC provided $\sim 5 \mathrm{mg}$ of protein per liter of cell culture. The MBP tag was cleaved from the activator using TEV protease with a His 6 tag. Upon cleavage of the MBP tag, the ReNHase TG328-2 activator protein was precipitated. Therefore, optimal conditions for stabilization of the activator were determined by employing a solubility screen, which indicated that the protein is soluble in $50 \mathrm{mM}$ HEPES (pH 8.0$), 300 \mathrm{mM} \mathrm{NaCl}$, and $10 \%$ glycerol. Under these conditions, the activator protein was stable at $4^{\circ} \mathrm{C}$ for several days.

\section{Sequence analysis}

A BLAST search on the ReNHase TG328-2 activator protein sequence revealed elements consistent with metal trafficking and GTPase activities. ${ }^{15}$ Specifically, there is significant similarity between the ReNHase TG328-2 activator protein and the COG0523 subgroup of the G3E family of P-loop GTPases. COG0523 constitutes a diverse group of proteins with unknown function and wide distribution, while 
the other three G3E family subgroups contain proteins known to be involved in metalloenzyme homeostasis such as HypB, UreG, and MeaB/ArgK. ${ }^{15}$ Structural information for proteins within the COG0523 subgroup is limited to the YjiA protein. ${ }^{34,35}$ Alignment of the ReNHase TG328-2 activator protein sequence with the Yija protein reveals that it shares broad sequence similarity (31\% sequence identity and $49 \%$ similarity) and a highly conserved cysteine-rich (CXCC) metal-binding motif (Figure 1). ${ }^{21}$ Like the YjiA protein, the Fe-type ReNHase TG328-2 activator protein also contains a P-loop (Walker A motif), which characteristically binds the triphosphate group of GTP, and a Walker B motif that is the site of magnesium binding. ${ }^{34}$ The presence of these motifs suggests that the ReNHase TG328-2 activator protein may possess GTPase activity, which has heretofore never been proposed for an iron-type NHase activator protein.

\section{GTPase activity}

GTPase activity was examined by quantifying free phosphate generated from GTP by reaction of a 1-3 $\mu \mathrm{M}$ sample of the ReNHase TG328-2 activator protein in $50 \mathrm{mM}$ HEPES and $5 \mathrm{mM} \mathrm{MgCl}_{2}$ at a pH of 8.0 using a malachite green assay (Table 1 ). Kinetic analysis reveals that the ReNHase TG328-2 Fe-type activator can, in fact, hydrolyze GTP with a $k_{\text {cat }}$ value of $1.2 \times 10^{-3} \mathrm{~s}^{-1}$ and a $K_{\mathrm{m}}$ value of $48 \mu \mathrm{M}\left(k_{\text {cat }} / K_{\mathrm{m}}\right.$ of $\left.30 \mathrm{~s}^{-1} \mathrm{M}^{-1}\right)$; these parameters are comparable with those for related GTPases such as the YjiA $\left(k_{\text {cat }}=6 \times 10^{-3} \mathrm{~s}^{-1}\right)$, YeiR $\left(k_{\text {cat }}=3 \times 10^{-3} \mathrm{~s}^{-1}\right)$, and Ras $\left(k_{\text {cat }}=3.4 \times 10^{-4} \mathrm{~s}^{-1}\right)$ proteins. ${ }^{34,36,37}$ The hydrolysis of GTP by the ReNHase TG328-2 activator protein is a previously unknown activity and may play a role in NHase metallocenter assembly.

Table 1 Kinetic data for the ReNHase TG328-2 activator NTPase activity toward NTP

$\begin{array}{llll}\text { NTP } & \boldsymbol{k}_{\text {cat }}\left(\mathbf{s}^{-\mathbf{1}}\right) & \boldsymbol{K}_{\mathbf{m}}(\boldsymbol{\mu M}) & \boldsymbol{k}_{\text {cat }} / \boldsymbol{K}_{\mathbf{m}}\left(\mathbf{s}^{-\mathbf{1}} \mathbf{M}^{-\mathbf{1}}\right) \\ \text { GTP } & (1.2 \pm 0.5) \times 10^{-3} & 40 \pm 20 & 30 \pm 20 \\ \text { GTP + cobalt } & (3.1 \pm 1.3) \times 10^{-3} & 170 \pm 80 & 20 \pm 10 \\ \text { ATP } & (1.0 \pm 0.2) \times 10^{-3} & 70 \pm 30 & 13 \pm 9 \\ \text { UTP } & (3.2 \pm 0.5) \times 10^{-4} & 90 \pm 20 & 4 \pm 1\end{array}$

Hydrolytic activity toward ATP and UTP was also examined to determine if the ReNHase TG328-2 activator protein is selective for GTP. Kinetic analysis revealed that the ReNHase TG328-2 activator

Biochemical Journal, Vol 474, No. 2 (January 15, 2017): pg. 247-258. DOI. This article is (C) Portland Press Limited and permission has been granted for this version to appear in e-Publications@Marquette. Portland Press Limited does not grant permission for this article to be further copied/distributed or hosted elsewhere without the express permission from Portland Press Limited. 
protein is capable of hydrolyzing ATP with a $k_{\text {cat }}$ of $1.0 \times 10^{-3} \mathrm{~s}^{-1}$ and a $K_{\mathrm{m}}$ of $70 \mu \mathrm{M}$, providing a catalytic efficiency $k_{\text {cat }} / K_{\mathrm{m}}$ of $13 \mathrm{~s}^{-1} \mathrm{M}^{-1}$, whereas UTP exhibits a $k_{\text {cat }}$ value of $3.2 \times 10^{-4} \mathrm{~s}^{-1}$ and a $K_{\mathrm{m}}$ of $90 \mu \mathrm{M}$, providing a catalytic efficiency $k_{\text {cat }} / K_{\mathrm{m}}$ of $4 \mathrm{~s}^{-1} \mathrm{M}^{-1}$ (Table 1 ). Although the rate of ATP hydrolysis is nearly identical with GTP, the $K_{\mathrm{m}}$ value increased by nearly two-fold. Therefore, based on catalytic efficiencies, the ReNHase TG328-2 activator protein prefers GTP, but is capable of hydrolyzing ATP and UTP.

GTP hydrolysis catalyzed by GTPases can be increased by as much as $10^{5}$ by GTPase effector proteins or cofactors, such as divalent metal ions. ${ }^{38}$ The addition of $\mathrm{Co}$ (II) as a nonoxidizable divalent metal ion probe for $\mathrm{Fe}$ (II) to the ReNHase TG328-2 activator protein in 50 $\mathrm{mM}$ HEPES and $5 \mathrm{mM} \mathrm{MgCl} 2$ at a $\mathrm{pH}$ of 8.0 doubled the observed rate of GTP hydrolysis but somewhat disrupted GTP binding, reducing the $k_{\text {cat }} / K_{\mathrm{m}}$ value from 30 to $20 \mathrm{~s}^{-1} \mathrm{M}^{-1}$ (Table 1 ). A similar finding was obtained for the YjiA protein in the presence of $\mathrm{Co}$, which reduced the $k_{\text {cat }} / K_{\mathrm{m}}$ value six-fold to $2.3 \mathrm{~s}^{-1} \mathrm{M}^{-1} .{ }^{34}$ On the other hand, the addition of $\mathrm{Zn}$ (II) to the YeiR protein enhanced both $k_{\text {cat }}$ and $K_{\mathrm{m}}$, resulting in an eight-fold increase in $k_{\text {cat }} / K_{\mathrm{m}} .{ }^{36}$ The observed four-fold increase in the GTP $K_{\mathrm{m}}$ value upon the addition of Co(II) to the ReNHase TG328-2 activator protein suggests that, unlike typical GTPases, the activator protein does not probably require accessory proteins to release GDP as GTPases typically exhibit GTP affinities in the picomolar to nanomolar range. ${ }^{37}$ Taken together, these data support the hypothesis that GTPase activity is related to divalent metal binding and, thus, metal homeostasis in NHase proteins.

\section{Divalent metal-binding properties}

Interestingly, the ReNHase TG328-2 activator protein contained no detectable iron, zinc, or nickel by ICP-AES even though it contains a cysteine-rich motif, which was proposed to be the metal-binding site. The lack of bound metal ions is probably the result of IMAC purification as $>50 \mathrm{mM}$ imidazole is used. Given the effect of divalent metal ions on the observed GTPase activity and the presence of the CXCC metalbinding motif, the divalent metal-binding properties of the ReNHase TG328-2 activator protein were investigated using Co(II) as a spectroscopic probe since Fe(II) exhibits no observable bands within

Biochemical Journal, Vol 474, No. 2 (January 15, 2017): pg. 247-258. DOI. This article is (C) Portland Press Limited and permission has been granted for this version to appear in e-Publications@Marquette. Portland Press Limited does not grant permission for this article to be further copied/distributed or hosted elsewhere without the express permission from Portland Press Limited. 
the visible absorption region, whereas the position and molar absorptivities of $\mathrm{Co}$ (II) $\mathrm{d}$ - $\mathrm{d}$ bands reflect the co-ordination number and geometry of the metal ions. ${ }^{39,40}$ UV-Vis spectra of 1 equiv. of Co(II) added to a $1 \mathrm{mM}$ solution of the ReNHase TG328-2 activator protein at $25^{\circ} \mathrm{C}$ in $50 \mathrm{mM}$ HEPES, $300 \mathrm{mM} \mathrm{NaCl}$, and $10 \%$ glycerol at a $\mathrm{pH}$ of 7.5 resulted in an increase in absorption at $\sim 530 \mathrm{~nm}$ with a normalized $\varepsilon_{530}$ of $\sim 90 \mathrm{M}^{-1} \mathrm{~cm}^{-1}$ (Figure 2). The molar absorptivity and position of this band suggest stoichiometric binding of $\mathrm{Co}$ (II) to the Fe-type activator protein in a distorted five-co-ordinate geometry. A significant increase in absorption at $310 \mathrm{~nm}$ is also observed but no distinct band is observable. Such absorptions are characteristic of an $\mathrm{S} \rightarrow \mathrm{Co}$ (II) ligand-to-metal charge transfer band, which is indicative of consistent with a $\mathrm{Co}(\mathrm{II})-S$-thiolate interaction.

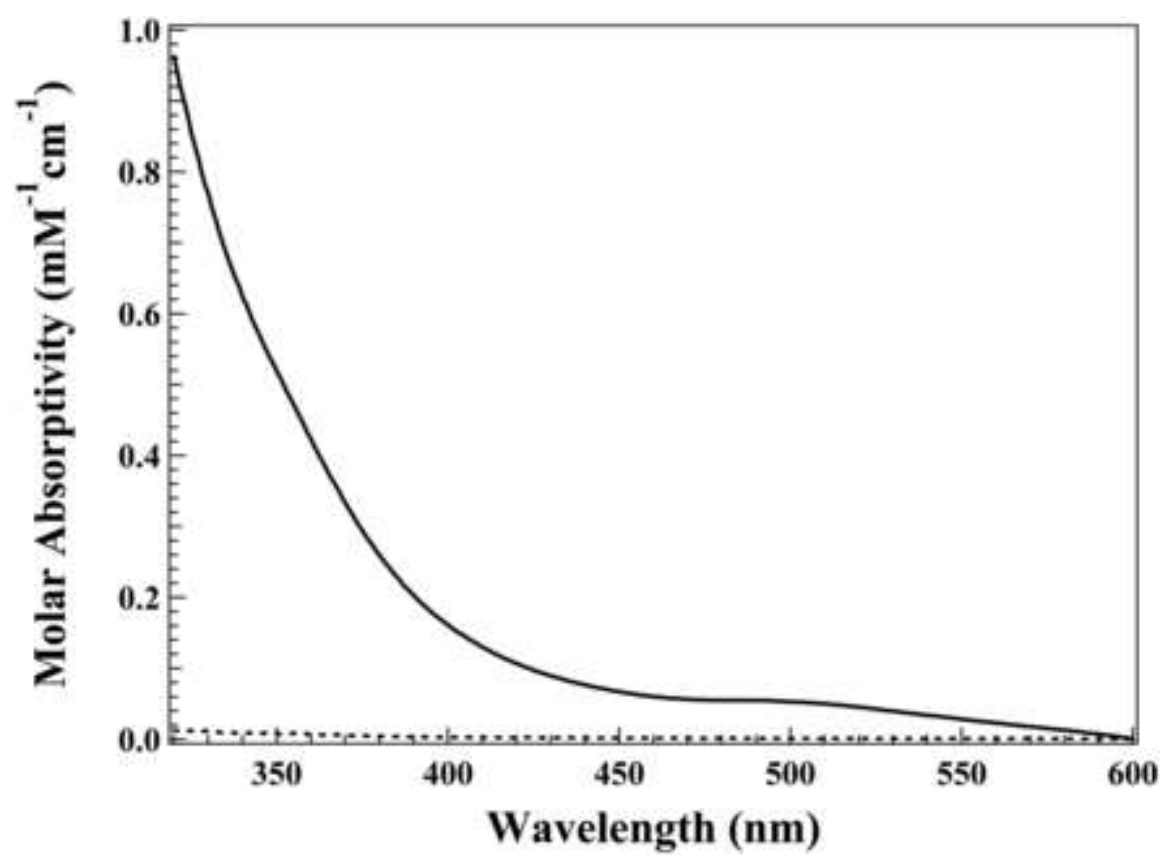

Figure 2. Electronic absorption spectra of the apo-ReNHast TG328-2 activator protein and the Co(II) form.

Electronic absorption spectra of the apo-ReNHase TG328-2 activator proteins were buffered in $50 \mathrm{mM}$ HEPES, pH $8.0,300 \mathrm{mM} \mathrm{NaCl}$, and $10 \%$ glycerol and spectra collected at $25^{\circ} \mathrm{C}$.

ITC measurements on the ReNHase TG328-2 activator protein were carried out on a MicroCal iTC200 ultrasensitive titration calorimeter at $25 \pm 0.2^{\circ} \mathrm{C}$ (Figure 3 ). The best fits obtained for the ReNHase TG328-2 activator protein provided an $n$ value of $0.87 \pm 0.02$ and a $K_{d}$ value of $2.9 \pm 0.2 \mu \mathrm{M}$. The binding of Co(II) by the ReNHase 
TG328-2 activator protein is exothermic $\left(\Delta H=-22.0 \pm 0.8 \mathrm{kcal} \mathrm{mol}^{-1}\right)$ and entropically driven $\left(\Delta S=48.5 \pm 0.5 \mathrm{cal} \mathrm{mol}^{-1} \mathrm{~K}^{-1}\right)$. As a control, Co(II) was titrated into EDTA-treated ReNHase TG328-2 activator protein in the absence of TCEP. No binding above the heat of dilution was observed, indicating that the reduction in a disulfide bond is required for divalent metal binding. The related YjiA protein binds 1 equiv. of $\mathrm{Co}$ (II) with a $K_{\mathrm{d}}$ of $2.0 \mu \mathrm{M}$, indicating that $\mathrm{Co}$ (II) binds to the ReNHase TG328-2 activator protein in a similar fashion to YjiA.

Time (min)

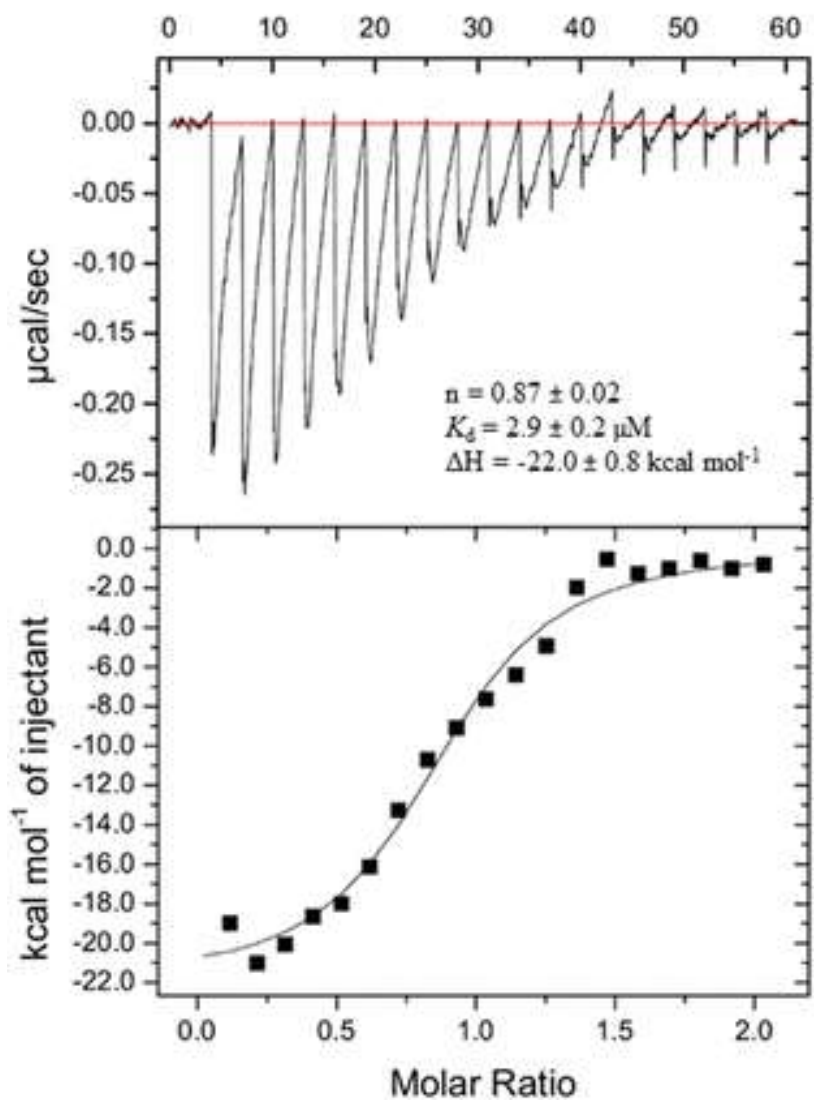

Figure 3. ITC data for Co(II) binding to the ReNHase TG328-2 activator protein in degassed $50 \mathrm{mM}$ HEPES buffer (pH 7.5) and $20 \mathrm{mM}$ TCEP, at $4^{\circ} \mathrm{C}$.

The activator solution $(50 \mu \mathrm{M})$ was stirred at $750 \mathrm{rpm}$ while adding $2 \mu \mathrm{l}$ of $\mathrm{Co}$ (II) titrant $(500 \mu \mathrm{M})$ delivered over $2 \mathrm{~s}$ with 3 min intervals between injections.

\section{CD studies}

CD spectra were recorded for the ReNHase TG328-2 activator protein in the absence and presence of GTP, GDP, Mg(II), and divalent metals ions (Figure $4 A, B$ ). The relative secondary structure

Biochemical Journal, Vol 474, No. 2 (January 15, 2017): pg. 247-258. DOI. This article is @ Portland Press Limited and permission has been granted for this version to appear in e-Publications@Marquette. Portland Press Limited does not grant permission for this article to be further copied/distributed or hosted elsewhere without the express permission from Portland Press Limited. 
deconvolution from the CD spectrum of the as-purified ReNHase TG328-2 activator protein resulted in 38\% a-helix and $17 \% \beta$-sheet (Table 2), similar to the YjiA protein (22\% a-helix and $26 \% \beta$-sheet). As is common with GTPases, ${ }^{41}$ the addition of GTP, under saturating GTP concentrations, or GDP to the ReNHase TG328-2 activator protein significantly altered the secondary structure (Figure 4A and Table 2); a marked decrease in a-helical character and an overall increase in disorder were observed in both cases, though the secondary structures with GTP and GDP, respectively, were distinguishable from the CD spectra. The observed conformational change upon GTP or GDP binding to the ReNHase TG328-2 activator protein is probably related to the interconnectivity of these cofactor binding sites. These data indicate a conformational change upon GTP binding and its hydrolysis to GDP, which is common for small GTPases. ${ }^{41}$
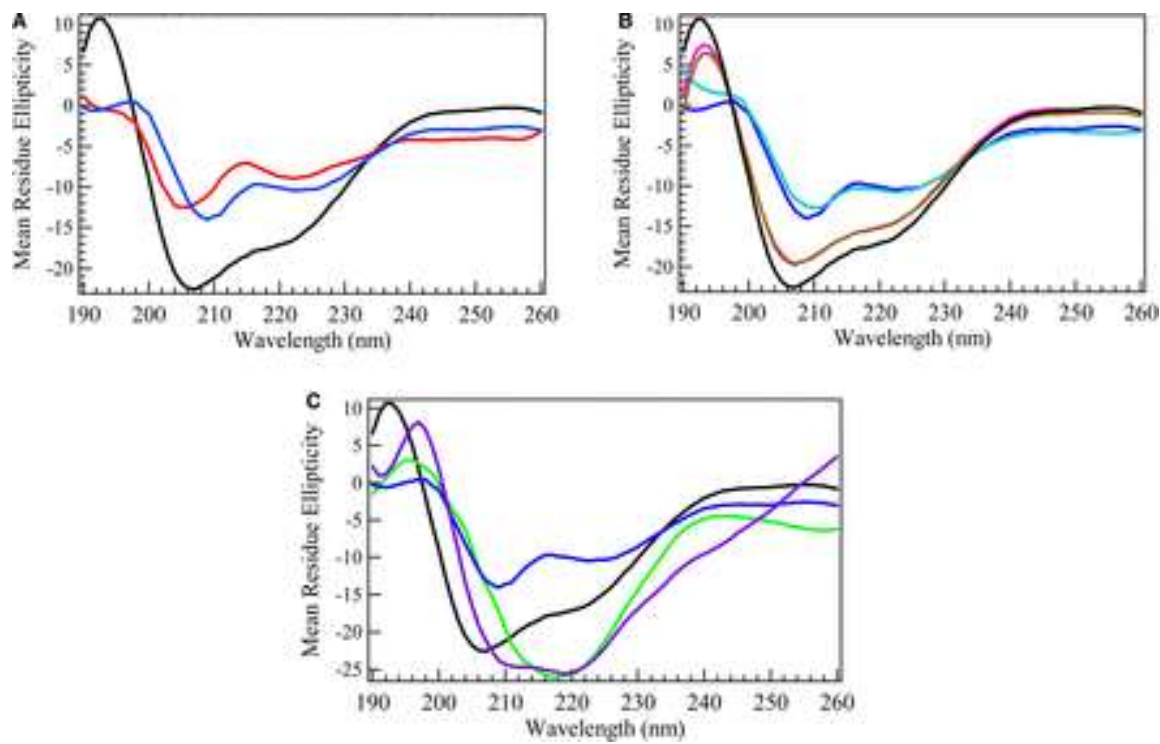

Figure 4. $C D$ spectra of ReNHase activator protein in bound and unbound forms. $\mathrm{CD}$ spectra of (A) $3 \mu \mathrm{M}$ ReNHase TG328-2 activator protein in $10 \mathrm{mM}$ sodium phosphate buffer at a pH of 7.5 in the absence (black) and presence of GTP (blue) and GDP (red). CD spectra of $3 \mu \mathrm{M}$ ReNHase TG328-2 activator protein was prepared in 10 $\mathrm{mM}$ sodium phosphate buffer at a pH of 7.5 in the presence of (B) Co(II) (pink), $\mathrm{Mg}$ (II) (brown), GTP + Mg(II) (light blue) and (C) ATP (green), UTP (purple) and spectra were collected in the 190 to $260 \mathrm{~nm}$ on samples in a $1 \mathrm{~mm}$ path-length quartz cell.

Biochemical Journal, Vol 474, No. 2 (January 15, 2017): pg. 247-258. DOI. This article is C Portland Press Limited and permission has been granted for this version to appear in e-Publications@Marquette. Portland Press Limited does not grant permission for this article to be further copied/distributed or hosted elsewhere without the express permission from Portland Press Limited. 
NOT THE PUBLISHED VERSION; this is the author's final, peer-reviewed manuscript. The published version may be accessed by following the link in the citation at the bottom of the page.

Table 2 Calculated percentages of secondary structure of free and bound ReNHase TG328-2 Fe activator derived from CD data using the CDSSTR algorithm

$\begin{array}{llll}\text { Sample } & \boldsymbol{a} \text {-Helix (\%) } & \boldsymbol{\beta} \text {-Sheet (\%) } & \text { Random coil (\%) (T + U) } \\ \text { Activator } & 38 & 17 & 46 \\ \text { GTP } & 20 & 27 & 53 \\ \text { GDP } & 8 & 30 & 62 \\ \text { Co(II) } & 31 & 30 & 38 \\ \text { Mg(II) } & 31 & 29 & 39 \\ \text { Mg(II) + GTP } & 34 & 32 & 49 \\ \text { ATP } & 45 & 26 & 30 \\ \text { UTP } & 50 & 23 & 26 \\ \text { Abbreviations: T, turns; U, unordered. }\end{array}$

As the ReNHase TG328-2 activator protein is a probable metallochaperone, $C D$ spectra were recorded at a $\mathrm{pH}$ of 7.5 in $10 \mathrm{mM}$ sodium phosphate buffer in the presence of 1 equiv. of $\mathrm{Co}$ (II) (Figure 4B). No significant conformational change was observed by CD upon the addition of either $\mathrm{Co}$ (II) or $\mathrm{Mg}$ (II) to ReNHase TG328-2 activator protein under conditions where binding is expected. Furthermore, the addition of $\mathrm{Mg}$ (II) had no effect on the secondary structure of the GTPbound protein. The nucleotide, therefore, appears to be the sole candidate for conformational change, other than perhaps interaction with the NHase a-subunit in any conceivable GTP-dependent mechanism for metal trafficking by the ReNHase TG328-2 activator protein. Intriguingly, ATP and UTP elicited a conformational change in marked contrast with those of GTP and GDP, in which a marked increase in the amount of a-helical structure was evident (Figure 4C). Given that ATP and UTP are hydrolyzed with reasonable efficiency relative to GTP, these data indicate that the conformational change per se is probably unconnected with NTPase activity. We speculate that the conformational change is, therefore, important in GTP-dependent iron trafficking and would expect, perhaps, that the hydrolysis of ATP and UTP would not similarly enhance iron trafficking.

\section{Homology model}

Currently, no three-dimensional X-ray crystal structure exists for an Fe-type NHase activator protein; therefore, a homological model was developed using the X-ray crystal structure of the Yjia protein (PDB: 1NIJ) as the template (Figure 5A). The resulting model was 
validated by the ProCheck and Verify 3D software. The Ramachandran plot of the ReNHase TG328-2 activator protein homology model revealed that only $1.5 \%$ of the structure is in a disallowed region. That combined with a QMEAN score of 0.506 indicates that the model is a reasonable predictive tool. The homology model of the ReNHase TG328-2 Fe-activator protein includes Walker A and Walker B motifs located on an a-helix and adjacent loop region, respectively, characteristic of typical GTPases. Three of the four residues of the DxxG Mg(II)-binding and GTP $Y$-phosphate-co-ordinating motif are located on a $\beta$-sheet, with the last residue on a loop. In addition, an SKTD sequence, similar to the NKED guanine-binding motif common to GTPases, is adjacent to the Walker A-binding site. Finally, the presumed metal-binding ( CXCC) motif is located on a $\beta$-sheet that is adjacent to the Walker B motif. Two of the Cys residues ( C74 and C72) reside on the same side of the $\beta$-sheet, suggesting that these two Cys residues can possibly form a disulfide bond. Since the divalent metalbinding site, $\mathrm{Mg}(\mathrm{II})$, and GTP-binding sites all reside in a row, this model suggests that there may be some interconnectivity of these cofactor binding sites.

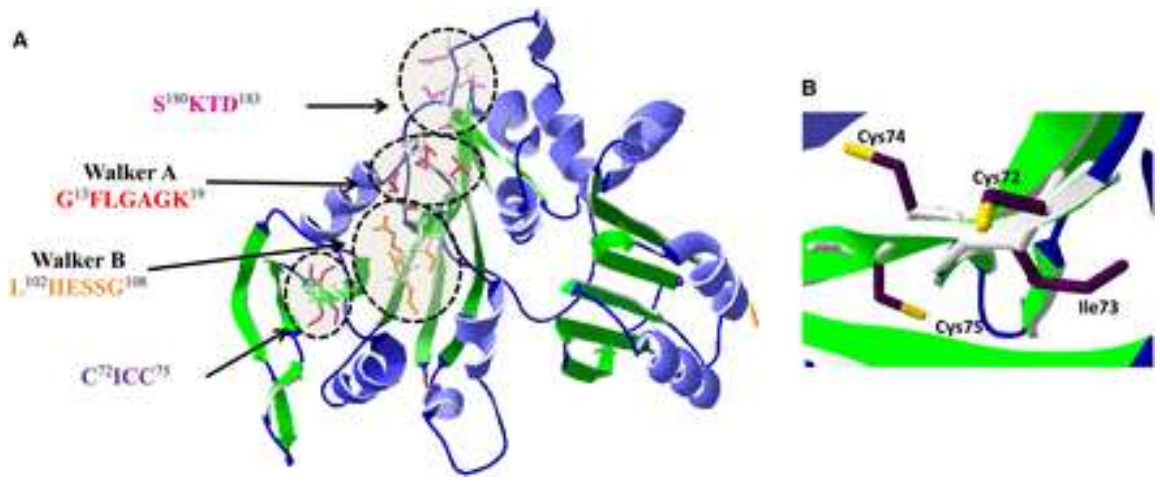

Figure 5. Homology model for the ReNHase TG328-2 activator. The residues making up the Walker $A$ and $B$ motifs highlighted along with the proposed thiolate metal-binding site and the guanine-binding motif. (B) An expanded view of the CXCC metal-binding site where it is clear that two of the cysteine residues (Cys 72 and Cys 74) are on the same side of the $\beta$-sheet.

\section{Conclusion}

An Fe-type NHase activator protein has been expressed and purified for the first time. Sequence analysis suggests the presence of a cysteine-rich divalent transition metal ion-binding motif and distinct GTPase motifs. Construction of a homology model, based on the

Biochemical Journal, Vol 474, No. 2 (January 15, 2017): pg. 247-258. DOI. This article is (C) Portland Press Limited and permission has been granted for this version to appear in e-Publications@Marquette. Portland Press Limited does not grant permission for this article to be further copied/distributed or hosted elsewhere without the express permission from Portland Press Limited. 
related Yjia protein, suggests that a majority of the key residues and sequences for metal-binding and GTPase activity are found on flexible loops, while the proposed divalent metal-binding site is located on a $\beta$ sheet adjacent to the Walker B motif. Kinetic studies indicate that the ReNHase TG328-2 activator protein exhibits GTPase activity and the addition of divalent metal ions such as Co(II) accelerated the rate of GTP hydrolysis, suggesting that GTP hydrolysis is potentially connected to the proposed metal chaperone function of the ReNHase TG328-2 activator protein. CD data reveal a significant conformational change in the ReNHase TG328-2 activator protein occurs upon the addition of GTP. This conformational change may be linked to recognition and binding of the activator protein to the NHase a-subunit. A combination of these data establishes, for the first time, that the ReNHase TG328-2 activator protein falls into the COG0523 subfamily of G3E P-Ioop GTPases, a diverse group of GTPases with proposed roles in metal homeostasis, and that GTPase activity is regulated by metal binding.

\section{Author Contribution}

N.G. prepared expression plasmid, carried out protein expression, purification, enzymatic assays, prepared samples for metal analysis, analyzed the results, developed the homology model, and wrote the paper with R.C.H.; K.P.W.L. performed the ITC experiments. R.C.H. and B.B. conceived of the idea and wrote the paper with N.G. and K.P.W.L.

\section{Funding}

We thank the National Science Foundation [CHE-1412443, R.C.H. and CHE1462201, B.B.] for funding this research.

\section{Competing Interests}

The Authors declare that there are no competing interests associated with the manuscript.

Abbreviations: ATP, adenosine triphosphate; CD, circular dichroism; EDTA, ethylenediaminetetraacetic acid; GTP, guanosine triphosphate; HEPES, 4-(2hydroxyethyl)piperazine-1-ethanesulfonic acid; ICP-AES, inductively coupled plasma atomic emission spectroscopy; ITC, isothermal titration calorimetry; MBP, maltose-binding protein; NHase, nitrile hydratase; NTP, nucleoside

Biochemical Journal, Vol 474, No. 2 (January 15, 2017): pg. 247-258. DOI. This article is (C) Portland Press Limited and permission has been granted for this version to appear in e-Publications@Marquette. Portland Press Limited does not grant permission for this article to be further copied/distributed or hosted elsewhere without the express permission from Portland Press Limited. 
NOT THE PUBLISHED VERSION; this is the author's final, peer-reviewed manuscript. The published version may be accessed by following the link in the citation at the bottom of the page.

triphosphate; PDB, protein database; TCEP, tris(2-carboxyethyl)phosphine; TEV, tobacco etch virus; UTP, uridine triphosphate.

\section{References}

${ }^{1}$ Yamada, H. and Kobayashi, M. (1996) Nitrile hydratase and its application to industrial production of acrylamide. Biosci. Biotech. Biochem. 60, 1391-1400doi:10.1271/bbb.60.1391

${ }^{2}$ Brady, D., Beeton, A., Zeevaart, J., Kgaje, C., van Rantwijk, F., and Sheldon, R.A. (2004) Characterisation of nitrilase and nitrile hydratase biocatalytic systems. Appl. Microbiol. Biotechnol. 64, 7685doi:10.1007/s00253-003-1495-0

${ }^{3}$ Kobayashi, M., Nagasawa, T., and Yamada, H. (1992) Enzymatic synthesis of acrylamide: a success story not yet over. Trends Biotechnol. 10, 402408doi: 10.1016/0167-7799(92)90283-2

${ }^{4}$ Nagasawa, T., Shimizu, H., and Yamada, H. (1993) The superiority of the third-generation catalyst, Rhodococcus rhodochrous $\mathrm{J} 1$ nitrile hydratase, for industrial production of acrylamide. Appl. Microbiol. Biotechnol. 40, 189-195doi:10.1007/BF00170364

${ }^{5}$ Nagasawa, T., and Yamada, H. (1995) Interrelations of chemistry and biotechnology-VI. Microbial production of commodity chemicals. Pure Appl. Chem. 67, 1241-1256doi:10.1351/pac199567071241

${ }^{6}$ Prasad, S., and Bhalla, T.C. (2010) Nitrile hydratases (NHases): at the interface of academia and industry. Biotechnol. Adv. 28, 725741doi:10.1016/j.biotechadv.2010.05.020

${ }^{7}$ Nagasawa, T., Mathew, C.D., Mauger, J., and Yamada, H. (1988) Nitrile hydratase-catalyzed production of nicotinamide from 3-Cyanopyridine in Rhodococcus rhodochrous J1. Appl. Environ. Microbiol. 54, 17661760 PMCID

${ }^{8}$ Kovacs, J.A., (2004) Synthetic analogues of cysteinate-ligated non-heme iron and non-corrinoid cobalt enzymes. Chem. Rev. 104, 825848doi: 10.1021/cr020619e

${ }^{9}$ Harrop, T.C., and Mascharak, P.K. (2004) Fe(III) and Co(III) centers with carboxamido nitrogen and modified sulfur coordination: lessons learned from nitrile hydratase. Acc. Chem. Res. 37, 253260doi:10.1021/ar0301532

${ }^{10}$ Tsujimura, M., Odaka, M., Nakayama, H., Dohmae, N., Koshino, H., Asami, T., (2003) A novel inhibitor for Fe-type nitrile hydratase: 2-cyano-2propyl hydroperoxide. J. Am. Chem. Soc. 125, 1153211538doi:10.1021/ja035018z

${ }^{11}$ Dey, A., Chow, M., Taniguchi, K., Lugo-Mas, P., Davin, S., Maeda, M., (2006) Sulfur K-edge XAS and DFT calculations on nitrile hydratase:

Biochemical Journal, Vol 474, No. 2 (January 15, 2017): pg. 247-258. DOI. This article is (C) Portland Press Limited and permission has been granted for this version to appear in e-Publications@Marquette. Portland Press Limited does not grant permission for this article to be further copied/distributed or hosted elsewhere without the express permission from Portland Press Limited. 
geometric and electronic structure of the non-heme iron active site. $J$. Am. Chem. Soc. 128, 533-541doi:10.1021/ja0549695

${ }^{12}$ Nishiyama, M., Horinouchi, S., Kobayashi, M., Nagasawa, T., Yamada, H., and Beppu, T. (1991) Cloning and characterization of genes responsible for metabolism of nitrile compounds from Pseudomonas chlororaphis B23. J. Bacteriol. 173, 2465-2472 PMCID

${ }^{13}$ Hashimoto, Y., Nishiyama, M., Horinouchi, S., and Beppu, T. (1994) Nitrile hydratase gene from Rhodococcus sp. N-774 requirement for its downstream region for efficient expression. Biosci. Biotechnol. Biochem. 58, 1859-1865doi:10.1271/bbb.58.1859

${ }^{14}$ Nojiri, M., Yohda, M., Odaka, M., Matsushita, Y., Tsujimura, M., Yoshida, T., (1999) Functional expression of nitrile hydratase in Escherichia coli: requirement of a nitrile hydratase activator and post-translational modification of a ligand cysteine. J. Biochem. 125, 696704doi:10.1093/oxfordjournals.jbchem.a022339

${ }^{15}$ Haas, C.E, Rodionov, D.A., Kropat, J., Malasarn, D., Merchant, S., and de Crecy-Lagard, V. (2009) A subset of the diverse COG0523 family of putative metal chaperones is linked to zinc homeostasis in all kingdoms of life. BMC Genomics 10, 470doi:10.1186/1471-2164-10470

${ }^{16}$ Cameron, R.A., Sayed, M., and Cowan, D.A. (2005) Molecular analysis of the nitrile catabolism operon of the thermophile Bacillus pallidus RAPc8. Biochim. Biophys. Acta 1725, 3546doi:10.1016/j.bbagen.2005.03.019

${ }^{17}$ Zhou, Z., Hashimoto, Y., Cui, T., Washizawa, Y., Mino, H., and Kobayashi, M. (2010) Unique biogenesis of high-molecular mass multimeric metalloenzyme nitrile hydratase: intermediates and a proposed mechanism for self-subunit swapping maturation. Biochemistry 49, 9638-9648doi:10.1021/bi100651v

${ }^{18}$ Zhou, Z., Hashimoto, Y., and Kobayashi, M. (2009) Self-subunit swapping chaperone needed for the maturation of multimeric metalloenzyme nitrile hydratase by a subunit exchange mechanism also carries out the oxidation of the metal ligand cysteine residues and insertion of cobalt. J. Biol. Chem. 284, 14930-14938doi:10.1074/jbc.M808464200

${ }^{19}$ Zhou, Z., Hashimoto, Y., Shiraki, K., and Kobayashi, M. (2008) Discovery of posttranslational maturation by self-subunit swapping. Proc. Natl Acad. Sci. U.S.A. 105, 14849-14854doi:10.1073/pnas.0803428105

${ }^{20}$ Cheng, T., Li, H., Yang, X., Xia, W., and Sun, H. (2013) Interaction of SlyD with HypB of Helicobacter pylori facilitates nickel trafficking. Metallomics 5, 804-807doi:10.1039/c3mt00014a

${ }^{21}$ Lu, J., Zheng, Y., Yamagishi, H., Odaka, M., Tsujimura, M., Maeda, M., (2003) Motif CXCC in nitrile hydratase activator is critical for NHase

Biochemical Journal, Vol 474, No. 2 (January 15, 2017): pg. 247-258. DOI. This article is (C) Portland Press Limited and permission has been granted for this version to appear in e-Publications@Marquette. Portland Press Limited does not grant permission for this article to be further copied/distributed or hosted elsewhere without the express permission from Portland Press Limited. 
NOT THE PUBLISHED VERSION; this is the author's final, peer-reviewed manuscript. The published version may be accessed by following the link in the citation at the bottom of the page.

biogenesis in vivo. FEBS Lett. 553, 391-396doi:10.1016/S00145793(03)01070-6

${ }^{22}$ Rzeznicka, K., Schätzle, S., Bottcher, D., Klein, J., and Bornscheuer, U.T. (2010) Cloning and functional expression of a nitrile hydratase (NHase) from Rhodococcusequi TG328-2 in Escherichia coli, its purification and biochemical characterisation. Appl. Microbiol. Biotechnol. 85, 1417-1425doi:10.1007/s00253-009-2153-y

${ }^{23}$ Donnelly, M.I., Zhou, M., Millard, C.S., Clancy, S., Stols, L., Eschenfeldt, W.H., (2006) An expression vector tailored for large-scale, highthroughput purification of recombinant proteins. Prot. Expr. Purif. 47, 446-454doi:10.1016/j.pep.2005.12.011

${ }^{24}$ Jancarik, J., Pufan, R., Hong, C., Kim, S.-H., and Kim, R. (2004) Optimum solubility (OS) screening: an efficient method to optimize buffer conditions for homogeneity and crystallization of proteins. Acta Crystallogr. D Biol. Crystallogr. D60, 16701673doi:10.1107/S0907444904010972

${ }^{25}$ Fusari, C., Demonte, A.M., Figueroa, C.M., Aleanzi, M., and Iglesias, A.A. (2006) A colorimetric method for the assay of ADP-glucose pyrophosphorylase. Anal. Biochem. 352, 145147doi:10.1016/j.ab.2006.01.024

${ }^{26}$ Whitmore, L., and Wallace, B.A. (2004) DICHROWEB, an online server for protein secondary structure analyses from circular dichroism spectroscopic data. Nucleic Acids Res. 32, W668W673doi:10.1093/nar/gkh371

${ }^{27}$ Whitmore, L., and Wallace, B.A. (2008) Protein secondary structure analyses from circular dichroism spectroscopy: methods and reference databases. Biopolymers 89, 392-400doi:10.1002/bip.20853

${ }^{28}$ Biasini, M., Bienert, S., Waterhouse, A., Arnold, K., Studer, G., Schmidt, T., (2014) SWISS-MODEL: modelling protein tertiary and quaternary structure using evolutionary information. Nucleic Acids Res. 42, 392400doi: 10.1093/nar/gku340

${ }^{29}$ Arnold, K., Bordoli, L., Kopp, J., and Schwede, T. (2006) The SWISS-MODEL workspace: a web-based environment for protein structure homology modelling. Bioinformatics 22, 195201doi:10.1093/bioinformatics/bti770

${ }^{30}$ Bordoli, L., Kiefer, F., Arnold, K., Benkert, P., Battey, J., and Schwede, T. (2008) Protein structure homology modeling using SWISS-MODEL workspace. Nat. Protoc. 4, 1-13doi: 10.1038/nprot.2008.197

${ }^{31}$ Guex, N., Peitsch, M.C., and Schwede, T. (2009) Automated comparative protein structure modeling with SWISS-MODEL and Swiss-PdbViewer: a historical perspective. Electrophoresis 30, S162S173doi:10.1002/elps.200900140

Biochemical Journal, Vol 474, No. 2 (January 15, 2017): pg. 247-258. DOI. This article is (C) Portland Press Limited and permission has been granted for this version to appear in e-Publications@Marquette. Portland Press Limited does not grant permission for this article to be further copied/distributed or hosted elsewhere without the express permission from Portland Press Limited. 
NOT THE PUBLISHED VERSION; this is the author's final, peer-reviewed manuscript. The published version may be accessed by following the link in the citation at the bottom of the page.

${ }^{32}$ Laskowski, R.A., MacArthur, M.W., Moss, D.S., and Thornton, J.M. (1993) PROCHECK: a program to check the stereochemical quality of protein structures. J. Appl. Crystallogr. 26, 283291doi:10.1107/S0021889892009944

${ }^{33}$ Eisenberg, D., Lüthy, R., and Bowie, J.U. (1997) [20] VERIFY3D: Assessment of protein models with three-dimensional profiles. In Methods in Enzymology. pp. 396-404, Academic Press

${ }^{34}$ Sydor, A.M., Jost, M., Ryan, K.S., Turo, K.E., Douglas, C.D., Drennan, C.L., (2013) Metal binding properties of Escherichia coli YjiA, a member of the metal homeostasis-associated COG0523 family of GTPases. Biochemistry 52, 1788-1801doi:10.1021/bi301600z

${ }^{35} \mathrm{Khil}$, P.P., Obmolova, G., Teplyakov, A., Howard, A.J., Gilliland, G.L., and Camerini-Otero, R.D. (2004) Crystal structure of the Escherichia coli YjiA protein suggests a GTP-dependent regulatory function. Prot. Struct. Funct. Bioinfor. 54, 371-374doi:10.1002/prot.10430

${ }^{36}$ Blaby-Haas, C.E., Flood, J.A., Crécy-Lagard, V.d., and Zamble, D.B. (2012) YeiR: a metal-binding GTPase from Escherichia coli involved in metal homeostasis. Metallomics 4, 488-497doi:10.1039/c2mt20012k

${ }^{37}$ Song, B.D., and Schmid, S.L. (2003) A molecular motor or a regulator? Dynamin's in a class of its own. Biochemistry 42, 13691376doi:10.1021/bi027062h

${ }^{38}$ Siderovski, D.P., and Willard, F.S. (2005) The GAPs, GEFs, and GDIs of heterotrimeric G-protein alpha subunits. Int. J. Biol Sci. 1, 5166doi:10.7150/ijbs.1.51

${ }^{39}$ May, S.W., and Kuo, J.-Y. (1978) Preparation and properties of cobalt(II) rubredoxin. Biochemistry 17, 3333-3338doi:10.1021/bi00609a025

${ }^{40}$ Vasak, M., and Kagi, J.H. (1981) Metal thiolate clusters in cobalt(II)metallothionein. Proc. Natl Acad. Sci. U.S.A. 78, 67096713doi:10.1073/pnas.78.11.6709

${ }^{41}$ Leipe, D.D., Wolf, Y.I., Koonin, E.V., and Aravind, L. (2002) Classification and evolution of P-loop GTPases and related ATPases. J. Mol. Biol. 317, 41-72doi:10.1006/jmbi.2001.5378

Biochemical Journal, Vol 474, No. 2 (January 15, 2017): pg. 247-258. DOI. This article is (C) Portland Press Limited and permission has been granted for this version to appear in e-Publications@Marquette. Portland Press Limited does not grant permission for this article to be further copied/distributed or hosted elsewhere without the express permission from Portland Press Limited. 